ONLINE MUTATION REPORT

\title{
Novel sarcoglycan gene mutations in a large cohort of Italian patients
}

\author{
C Boito, M Fanin, G Siciliano, C Angelini, E Pegoraro
}

J Med Genet 2003;40:e67 (http://www.jmedgenet.com/cgi/content/full/40/5/e67)

$\mathrm{T}$ he sarcoglycanopathies are a group of autosomal recessive limb girdle muscular dystrophies (LGMD) resulting from mutations in the genes encoding sarcoglycans (SG), small glycoproteins localised to the plasma membrane of muscle fibres. The sarcoglycans consist of a single transmembrane domain, a small intracellular domain, and a large extracellular domain, and their molecular weight ranges from 35 to $50 \mathrm{kDa}$. The sarcoglycan complex, which is composed of $\alpha$-SG, $\beta$-SG, $\gamma$-SG, and $\delta$-SG, is part of the dystrophin associated glycoprotein (DAG) complex, and it acts as a link between the extracellular matrix and the cytoskeleton, confers structural stability to the sarcolemma, and protects muscle fibres from mechanical stress during muscle contraction. ${ }^{1-3}$

The diseases associated with SG gene mutations ( $\alpha$-SG (SGCA), LGMD2D, MIM 600119; $\beta$-SG (SGCB), LGMD2E, MIM 604286; $\gamma$-SG (SGSG), LGMD2C, MIM 253700; $\delta$-SG (SGCD), LGMD2F, MIM 601287) are rare disorders in the general population, but represent a sizeable proportion of all muscular dystrophies with normal dystrophin (about 10-20\% of cases $).{ }^{4-8}$ LGM2D is the most frequent sarcoglycanopathy, ${ }^{9}$ followed by LGMD2C ${ }^{10}$ and LGMD2E, ${ }^{11}{ }^{12}$ while the most rare is LGMD2F. ${ }^{13}$

Since the first description of SG gene mutation in LGMD2D, ${ }^{914}$ a large number of patients and mutations have been described, ${ }^{10-13} 15-28$ and correlations of genotype with clinical phenotype and protein expression have been investigated ${ }^{29}{ }^{30}$ Null mutations in any of the SG genes usually result in a severe phenotype (sometimes resembling Duchenne-like muscular dystrophy) and at the muscle biopsy level absence of the corresponding protein, whereas missense mutations have variable effects on both phenotype and protein level.

Studies of muscle biopsies from patients with null mutations in the SG genes showed that the absence of one SG subunit has consequences for the stability of the entire complex depending on which SG is mutated. Assembly of the SG complex to the membrane is dependent upon the cosynthesis of all components. ${ }^{31}$ This explains why the loss of one SG component drives the secondary loss or reduction in the other SGs, leading to destabilisation of the DAG complex, and sarcolemmal damage. ${ }^{32}{ }^{33}$ Current pathogenetic hypotheses suggest that mutated SGs may fail to assemble because they are not competent to traffic to the sarcolemma. The failure in SG targeting may result in a rapid degradation of the mislocated protein. ${ }^{34}$

Considerable inter- and intrafamilial clinical heterogeneity have been reported in sarcoglycanopathies. ${ }^{14} 183536$ The clinical spectrum of these disorders includes proximal myopathy, myoglobinuria, raised serum CK, and dilated cardiomyopathy. ${ }^{37-40}$

The diagnosis in sarcoglycanopathy patients is sometimes prompted by the detection of SG deficiency on muscle biopsy by immunofluorescence or immunoblotting analyses. The finding of SG deficiency warrants subsequent gene mutation analysis. ${ }^{41}$ Here, we report a study of SG gene mutations in a

\section{Key points}

- We studied a group of 291 limb girdle muscular dystrophy/myopathy patients, with raised CK to identify primary sarcoglycanopathy patients. Patients suitable for $\alpha-, \beta-, \gamma$, and $\delta$-sarcoglycan gene mutation studies were selected on the basis of a decreased amount of $\alpha$-sarcoglycan protein assessed by immunoblot analysis on muscle biopsies.

- Seventeen patients $(17 / 291,5.8 \%)$ showed reduced $\alpha$-sarcoglycan protein. Two patients $(2 / 17, \sim 12 \%)$ showed complete deficiency and $15(15 / 17,88 \%)$ a partial deficiency, ranging from $5 \%$ to $50 \%$ of controls. All four $\alpha-, \beta-, \gamma$, and $\delta$-sarcoglycan genes were screened for potential mutations in the 17 patients showing $\alpha$-sarcoglycan deficiency by RT-PCR/SSCP/ direct sequencing. Sarcoglycan gene mutations were detected in 12 of the 17 patients $(-70 \%)$. Seven patients showed $\alpha$-sarcoglycan $(7 / 17,41 \%)$, one $\beta$-sarcoglycan $(1 / 17, \sim 6 \%)$, three $\gamma$-sarcoglycan $(3 / 17, \sim 18 \%)$ and one $\delta$-sarcoglycan $(1 / 17, \sim 6 \%)$ gene mutations. Of the 14 mutations identified eight were novel.

- Our study suggests that $\alpha$-sarcoglycan immunoblotting is a sensitive screening tool to detect primary sarcoglycan deficient patients. Protein analysis must precede sarcoglycan gene analysis. The clinical phenotype in our series includes asymptomatic patients with raised CK and severe DMD-like and limb girdle muscular dystrophy presentation with or without cardiomyopathy, widening the clinical spectrum described so far in primary sarcoglycanopathies.

cohort of muscular dystrophy/myopathy patients of unknown aetiology selected via $\alpha$-SG immunoblot analysis.

\section{MATERIAL AND METHODS}

\section{Patients}

About 2000 consecutive muscle biopsies from the tissue bank of the Neuromuscular Unit of the University of Padova were screened for patients meeting one or more of the following clinical and laboratory criteria: (1) raised CK (>1000 U/1); (2) progressive muscle weakness; 3 ) onset in the first or second decade of life; (4) normal dystrophin by immunohistochemistry and/or immunoblotting; (5) muscle histopathology consistent with a muscular dystrophy or myopathy. Two hundred and ninety-one muscle biopsies were selected and analysed with $\alpha$-sarcoglycan immunoblotting.

Seventeen patients showed reduced or absent $\alpha$-sarcoglycan in their muscle biopsy and were chosen for sarcoglycan gene studies. A DMD-like phenotype was assigned to those patients with onset of muscle weakness before the age of 5 years, rapid progression of weakness, and loss of ambulation before 14 years of age. 
Table 1 Clinical and molecular data in sarcoglycanopathy patients

\begin{tabular}{|c|c|c|c|c|c|c|c|c|c|c|c|c|c|c|}
\hline \multirow[b]{2}{*}{ Patient No } & \multirow[b]{2}{*}{ Sex } & \multirow{2}{*}{$\begin{array}{l}\text { Family } \\
\text { history }\end{array}$} & \multirow{2}{*}{$\begin{array}{l}\text { Age of } \\
\text { onset (y) }\end{array}$} & \multirow[b]{2}{*}{ Clinical phenotype } & \multirow{2}{*}{$\begin{array}{l}\text { Cardiac } \\
\text { involvement }\end{array}$} & \multicolumn{4}{|c|}{ Sarcoglycan immunolabelling } & \multirow{2}{*}{$\begin{array}{l}\alpha \text {-sarcoglycan } \\
\text { immunoblotting } \\
(\%)\end{array}$} & \multirow[b]{2}{*}{ Genomic variation } & \multirow{2}{*}{$\begin{array}{l}\text { Mutated } \\
\text { sarcoglycan } \\
\text { exon }\end{array}$} & \multirow{2}{*}{$\begin{array}{l}\text { Protein } \\
\text { alteration }\end{array}$} & \multirow[b]{2}{*}{ Protein domain } \\
\hline & & & & & & $\alpha$ & $\beta$ & $\gamma$ & $\delta$ & & & & & \\
\hline \multicolumn{15}{|c|}{ a-sarcoglycanopathy } \\
\hline $\begin{array}{l}1 \\
(2668)\end{array}$ & $\mathrm{F}$ & - & 4 & $\begin{array}{l}\text { DMD-like } \\
\text { (WCB } 12 \text { y) }\end{array}$ & ND & - & - & - & - & 0 & $\begin{array}{l}\text { IVS5 -1 delG/-2 A>T } \\
\text { (homo) }\end{array}$ & 6 & PTC+3aa & Extracellular \\
\hline $\begin{array}{l}2 \\
(5298)\end{array}$ & M & - & 4 & $\begin{array}{l}\text { LGMD } \\
\text { (WCB } 36 \text { y) }\end{array}$ & ND & +++- & ++++ & ++++ & ++++ & $40^{*}$ & $421 \mathrm{C}>\mathrm{A}$ & 4 & R141S & Extracellular \\
\hline $\begin{array}{l}3 \\
(5262)\end{array}$ & M & - & 8 & Calf hypertrophy & - & ++- & +++ & +++ & ++- & $40^{*}$ & $\begin{array}{l}541 \mathrm{C}>\mathrm{T} \\
86 \text { insA }\end{array}$ & $\begin{array}{l}5 \\
2\end{array}$ & $\begin{array}{l}\text { R181C } \\
\text { PTC+14aa }\end{array}$ & $\begin{array}{l}\text { Extracellular } \\
\text { Extracellular }\end{array}$ \\
\hline $\begin{array}{l}4 \\
(5321)\end{array}$ & $\mathrm{F}$ & - & 10 & LGMD & - & +- & +++ & ++++ & +++ & 20 & $\begin{array}{l}229 C>T \\
850 C>T\end{array}$ & $\begin{array}{l}3 \\
7\end{array}$ & $\begin{array}{l}\text { R77C } \\
\text { R284C }\end{array}$ & $\begin{array}{l}\text { Extracellular } \\
\text { Extracellular }\end{array}$ \\
\hline $\begin{array}{l}5 \\
(5893)\end{array}$ & $\mathrm{F}$ & - & 10 & LGMD & ND & +- & +- & ++- & ++- & 0 & $\begin{array}{l}293 \mathrm{G}>\mathrm{A} \\
\text { (homo) }\end{array}$ & 3 & $\mathrm{R} 98 \mathrm{H}$ & Extracellular \\
\hline $\begin{array}{l}6 \\
(2786)\end{array}$ & $\mathrm{F}$ & + & 11 & $\begin{array}{l}\text { LGMD } \\
\text { (WCB } 28 \text { y) }\end{array}$ & - & +- & +- & +- & +- & 10 & $850 \mathrm{C}>\mathrm{T}$ & 7 & R284C & Extracellular \\
\hline $\begin{array}{l}7 \\
(5004)\end{array}$ & M & + & 14 & Calf hypertrophy & ND & +- & ++- & ++- & ++- & 5 & $662 \mathrm{G}>\mathrm{A}$ & 6 & $\mathrm{R} 221 \mathrm{H}$ & Extracellular \\
\hline \multicolumn{15}{|c|}{$\beta$-sarcoglycanopathy } \\
\hline $\begin{array}{l}8 \dagger \\
(1065)\end{array}$ & $M$ & - & 7 & LGMD/DCM & + & +- & +- & +- & +- & 10 & $\begin{array}{l}-22+10 \text { dup } \\
\text { (homo) }\end{array}$ & 1 & $\mathrm{PTC}+25 \mathrm{aa}$ & Cytoplasmic \\
\hline \multicolumn{15}{|c|}{$\gamma$-sarcoglycanopathy } \\
\hline $\begin{array}{l}9 \\
(2439)\end{array}$ & $\mathrm{F}$ & + & 4 & DMD-like & - & ++- & ++- & - & ++++ & 10 & $\begin{array}{l}848 \mathrm{G}>\mathrm{A} \\
\text { (homo) }\end{array}$ & 8 & С283T & Extracellular \\
\hline $\begin{array}{l}10 \\
(2736)\end{array}$ & $\mathrm{F}$ & - & 7 & Calf hypertrophy & - & ++- & +- & - & ++- & 5 & $\begin{array}{l}128 \mathrm{~T}>\mathrm{G} \\
517 \mathrm{delT}\end{array}$ & $\begin{array}{l}2 \\
6\end{array}$ & $\begin{array}{l}\text { L43X } \\
\text { PTC+19aa }\end{array}$ & $\begin{array}{l}\text { Transmembrane } \\
\text { Extracellular }\end{array}$ \\
\hline 11 & $\mathrm{~F}$ & adopted & 4 & $\begin{array}{l}\text { DMD-like/DCM } \\
\text { (WCB 9 y) }\end{array}$ & + & +- & +++- & - & ++++ & 5 & $87 \mathrm{ins} T$ & 2 & $\mathrm{PTC}+28 \mathrm{aa}$ & Cytoplasmic \\
\hline \multicolumn{15}{|c|}{$\delta$-sarcoglycanopathy } \\
\hline $\begin{array}{l}12 \dagger \\
(4480)\end{array}$ & $\mathrm{F}$ & + & 4 & $\begin{array}{l}\text { DMD-like } \\
\text { (WCB } 13 \text { y) }\end{array}$ & ND & +- & +- & +- & +- & 10 & $\begin{array}{l}593 \mathrm{G}>\mathrm{C} \\
\text { (homo) }\end{array}$ & 7 & R198P & Extracellular \\
\hline
\end{tabular}


Sarcoglycan immunohistochemistry and $\alpha$-sarcoglycan immunoblotting

Sarcoglycan immunohistochemistry was done as previously described. ${ }^{21}$ Briefly, patients' muscle biopsy cryosections, $6 \mu \mathrm{m}$ thick, were incubated for one hour at room temperature with the following antibodies: $\alpha$-sarcoglycan (1:20), $\beta$-sarcoglycan (1:100), $\gamma$-sarcoglycan (1:100), and $\delta$-sarcoglycan (1:100). All the antibodies were from Novocastra (Novocastra, Newcastle upon Tyne, UK). After three washes in PBS for five minutes each, anti-mouse cyanine- 3 conjugated $(1: 100)$ (Caltag, Burlingame, CA) was used for 30 minutes. Sections were mounted with anti-fading medium. The visualisation of mounted sections was done on an Zeiss Axioskop photomicroscope. Immunolabelling of all four sarcoglycans was scored by visual inspection by two independent investigators in comparison to a normal control. The intensity of the signal was graded from normal $(++++)$, to complete absence $(---)$.

Immunoblot analysis was performed from cryosections of patients' muscle biopsies. Briefly, muscle biopsy cryosections were dissolved in Laemmli buffer and electrophoresed on 3.5$12 \%$ polyacrylamide gels. Proteins were electroblotted to nitrocellulose membranes. Post transfer gels were stained with Coomassie blue to assess the myosin content of each muscle biopsy. The blots were air dried and immunostained with anti- $\alpha$-sarcoglycan antibodies (1:800) (Novocastra, Newcastle upon Tyne, UK) for one hour. Anti-mouse biotinylated (1:1000) (Amersham, Rainham, UK) and streptavidinhorseradish peroxidase complex $(1: 1,000)$ (Amersham) antibodies were used to visualise the immunocomplexes. The blots were developed using the enhanced chemiluminescence method with luminol (ECL, Amersham). Semiquantitation of the sarcoglycan proteins was done adjusting for the protein content of each muscle biopsy.

\section{Sarcoglycan gene mutations studies}

A total of 10-50 ng of frozen muscle biopsy was homogenised using a Kinematica Polytron PT2100 homogeniser. Total RNA was extracted using Trizol (Gibco, BRL) according to the manufacturer's instructions and stored in RNAse free water at $-80^{\circ} \mathrm{C}$. For cDNA synthesis about 1-2 $\mu \mathrm{g}$ of total RNA were reverse transcribed using oligo-dT primers as previously described. ${ }^{42}$ The entire coding regions of $\alpha-, \beta-, \delta-$, and $\gamma$-sarcoglycan genes were amplified by sets of overlapping primers and subjected to PCR as previously described. ${ }^{513} 18$ Three different SSCP (single strand conformational polymorphism) conditions were used for screening for sarcoglycan gene mutations. ${ }^{5}$ The identified conformers were reamplified using the original amplification primer and PCR conditions as previously described. ${ }^{5}$ Only the detected conformers were directly automatically sequenced (CRIBI Biotechnology Centre, University of Padova).

The sarcoglycan gene mutations identified were confirmed with the appropriate restriction endonuclease digestion if a gain or loss of restriction site was detected or with appropriate PCR primers designed to cover the mutated region, and the PCR product was size fractioned with denaturing polyacrylamide gel electrophoresis (primer sequences available upon request). Each novel mutation was assessed on 100 normal chromosomes. The autosomal recessive pattern of inheritance was confirmed in the genomic DNA of the patients' parents when available.

\section{RESULTS}

Monoclonal antibodies directed against $\alpha$-sarcoglycan were used to screen muscle biopsies of patients affected with muscular dystrophy/myopathy of unknown aetiology to identify potential primary sarcoglycanopathies. Seventeen patients showed reduced $\alpha$-sarcoglycan protein by immunoblot analysis of their muscle biopsies. Two patients $(2 / 17, \sim 12 \%)$ showed complete deficiency and 15 a partial deficiency, ranging from

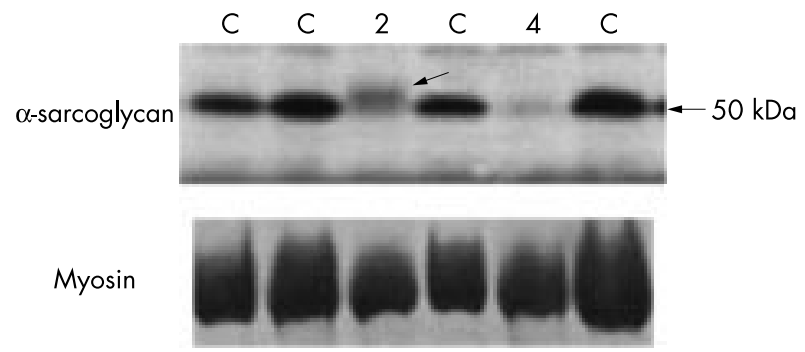

Figure 1 Immunoblot analysis of muscle biopsies from two $\alpha$-sarcoglycan deficient patients showing partial $\alpha$-sarcoglycan deficiency. Shown is $\alpha$-sarcoglycan immunoblot analysis of patients 2 and 4 and control muscle containing normal $\alpha$-sarcoglycan. The lower panel is the corresponding post-transfer gel stained with Coomassie Blue to visualise the myosin heavy chain protein used for normalising myofibre protein content of samples. A doublet of bands is shown for $\alpha$-sarcoglycan in patient 2; the bottom band (arrow) corresponds to the $50 \mathrm{kDa}$ normal size $\alpha$-sarcoglycan protein, and the top band to higher molecular weight $\alpha$-sarcoglycan positive material. This band may represent a degradation product owing to the instability of the dystrophin-glycoprotein complex following sarcoglycan deficiency itself. Less than $20 \%$ of normal control $\alpha$-sarcoglycan is detectable in patient 4 's muscle biopsy (values adjusted to the protein content of muscle samples).

$5-50 \%$ of controls (15/17, 88\%). Two patients (Nos 2 and 3, table 1) showed a doublet bands for $\alpha$-sarcoglycan on immunoblotting; in both there was one band corresponding to the normal $50 \mathrm{kDa} \alpha$-sarcoglycan and an additional band of decreased molecular weight at about $48 \mathrm{kDa}$ in patient 2 and of increased molecular weight at about $55 \mathrm{kDa}$ in patient 3 (fig 1).

Immunohistochemistry of all four sarcoglycan proteins showed consistent results in $\alpha-, \beta-$, and $\delta$-sarcoglycanopathy patients (table 1). In $\gamma$-sarcoglycanopathy, the complete absence of $\gamma$-sarcoglycan was associated with a variable reduction of the other three proteins (table 1). Patients showing by immunoblotting a reduction of $\alpha$-sarcoglycan in their muscle biopsy ranging from 0 to $20 \%$ of normal had by $\alpha$-sarcoglycan immunohistochemistry a variable reduction of labelling ranging from absent to moderate (table 1 ). The only two patients showing by immunoblot more than $20 \%$ of the protein (Nos 2 and 3, table 1) had a mild or moderate reduction of labelling of $\alpha$-sarcoglycan (table 1).

All four $\alpha-, \beta-, \gamma-$, and $\delta$-sarcoglycan genes were screened for pathogenetic mutations in the 17 patients showing $\alpha$-sarcoglycan deficiency. Sarcoglycan gene mutations were detected in 12 of the 17 patients $(\sim 70 \%)$. Seven patients showed $\alpha$-sarcoglycan $(7 / 17,41 \%)$, one $\beta$-sarcoglycan ( $1 / 17$, $\sim 6 \%)$, three $\gamma$-sarcoglycan $(3 / 17, \sim 18 \%)$, and one $\delta$-sarcoglycan $(1 / 17, \sim 6 \%)$ gene mutations (table 1). Family history, clinical presentation, and sarcoglycan gene and protein data for each patient are summarised in table 1.

\section{$\alpha$-sarcoglycan}

Nine $\alpha$-sarcoglycan gene mutations were identified and five of them were novel. All of them were located in the extracellular, amino-terminal domain of the protein. Seven were missense changes (in six patients), one was a single base pair out of frame insertion, and one mutation altered the acceptor splice site of intron 5 (table 1). Twenty-seven percent of the mutated chromosomes (3/11) had variations in exon 3 (table 1 ).

Patients 1 and 5 showed complete absence of $\alpha$-sarcoglycan. Patient 1 also had a complete loss of the sarcoglycan complex, and a severe phenotype with early onset (4 years) and loss of ambulation at 12 years of age, while patient 5 is still ambulant with bilateral support at 43 years of age (table 1). Patient 1 harboured a complex mutation affecting the acceptor splice site of exon 6 , a single base pair deletion at position -1 , and an in cis point mutation at position -2 (IVS $-1 \mathrm{delG} /-2 \mathrm{~A}>\mathrm{G}$ ) abolishing the correct splicing of exon 5 to exon 6 . Both mutations 
SSCP

8. SG435F - 748R

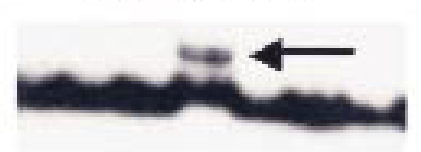

Direct sequencing

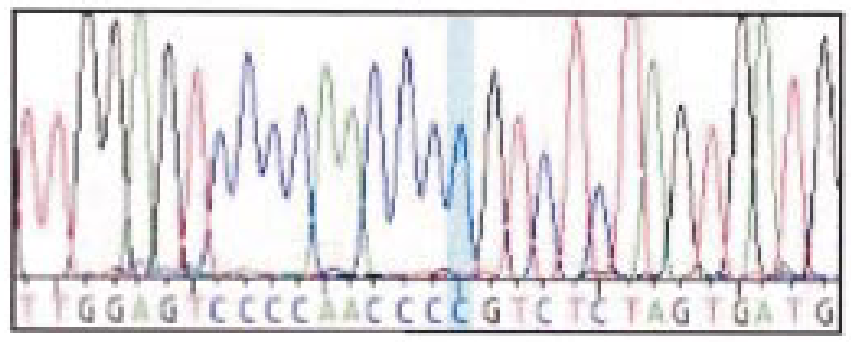

Mpsl digestion

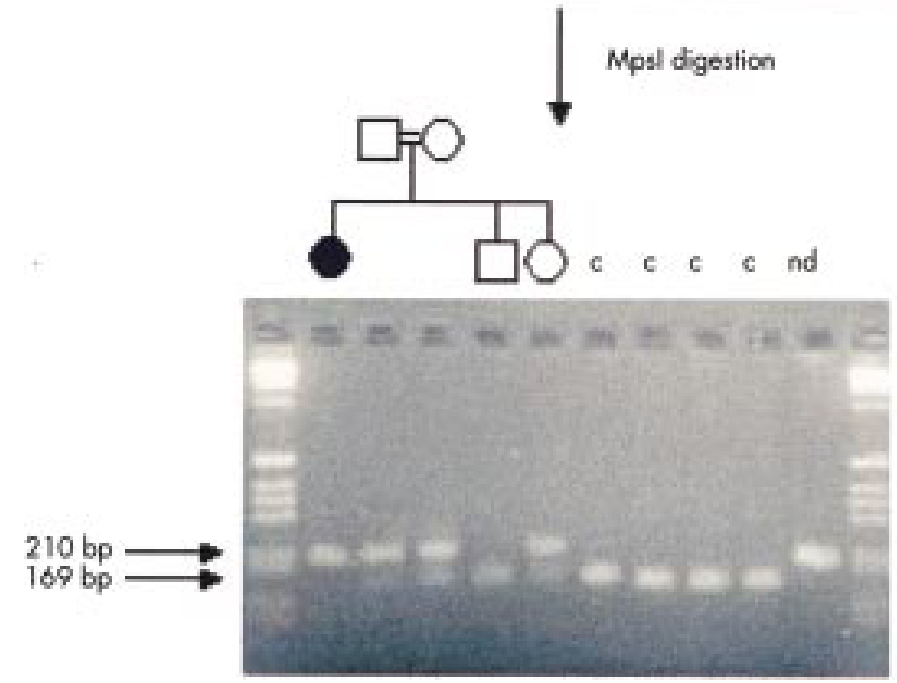

$593 \mathrm{G} \times \mathrm{C}$

RI9BP

Figure 2 Screening of the $\delta$-sarcoglycan coding sequence for potential mutations by single stranded conformational polymorphism (SSCP) showed a G593C homozygous nucleotide change resulting in a R198P amino acid change in patient 12. In the top panel, SSCP analysis of RT-PCR product for primer set 435F-748R showed a unique conformer in patient 12. Direct sequencing of the aberrant conformer showed a $G$ to $C$ nucleotide change at position 593 of the $\delta$-sarcoglycan coding sequence (middle panel) resulting in an arginine to proline amino acid change at position 198 of the $\alpha$-sarcoglycan protein. Nucleotide change G593G resulted in a loss of Mpsl restriction enzyme site. Primers were designed to amplify exon 7 of the $\delta$-sarcoglycan gene and the PCR product was digested with Mpsl. Digestion fragments were present in 100 control chromosomes, in none of patient 12's chromosomes, and only in one of the patient's parents' and unaffected sister's chromosomes (heterozygous mutation) (bottom panel).

were homozygous. SSCP analysis using a forward primer in exon 5 and a reverse primer in exon 7 of the $\alpha$-sarcoglycan coding sequence showed a homozygous out of frame deletion of exon 6. SSCP analysis of exon 6 flanking splice sites showed in this patient $\mathrm{a}-\mathrm{l}$ delG/-2 $\mathrm{A}>\mathrm{G}$ of the acceptor splice site of intron 5. The mutations in the intron did not cause any loss or gain of a restriction site enzyme and SSCP using the original primer set was done in the patient, her parents, and 100 normal chromosomes. SSCP analysis showed that the same mutation was inherited from both parents. In this patient, an insertion of $80 \mathrm{bp}$ at the end of intron 6 was identified owing to the use of a cryptic splice site.

Of the remaining five patients, three had a LGMD phenotype (patients 2, 4, and 6) and two presented with calf hypertrophy and raised CK level. Interestingly, in two patients (Nos 2 and 3) harbouring heterozygous missense changes, $\alpha$-sarcoglycan was mildly reduced (about $40 \%$ of controls), but on $\alpha$-sarcoglycan immunoblotting extra bands at about 55 $\mathrm{kDa}$ and $48 \mathrm{kDa}$ were detected (table 1, fig 1). Thus, of the seven patients studied, two were compound heterozygous (patients 3 and 4), two were homozygous (patients 1 and 5), and in three only one $\alpha$-sarcoglycan mutation was identified (patients 2, 6, and 7) (table 1).

\section{$\beta$-sarcoglycan}

$\beta$-sarcoglycan gene mutations were identified in only one patient (table 1, patient 8). This patient showed a novel, homozygous out of frame duplication spanning nucleotide 21 to nucleotide 52 of the $\beta$-sarcoglycan coding sequence (accession No XM_003553). This duplication encompassed 22 bp before the ATG and $10 \mathrm{bp}$ in exon 1 of the $\beta$-sarcoglycan gene, and caused a frameshift with a stop codon 25 amino acids downstream of the mutation (table 1). This patient was from a consanguineous family and presented at 7 years of age with mild muscle weakness, which has progressed since then. At 21 years the patient developed a dilated cardiomyopathy. At 37 years of age the patient showed a marked waddling gait, with proximal muscle weakness in the upper and lower limb. 


\section{$\gamma$-sarcoglycan}

Three patients had $\gamma$-sarcoglycan gene mutations. Patient 9 was homozygous for the C283T variation found in Gypsies, patient 10 was a compound heterozygote for a novel nonsense change (L43X) and a single thymine deletion at position 517 of the $\gamma$-sarcoglycan gene, and patient 11 was heterozygous for an out of frame single thymine insertion at position 87. Interestingly, the $128 \mathrm{~T}>\mathrm{G}$ resides in the transmembrane domain of the $\gamma$-sarcoglycan protein. Clinical phenotype was severe DMD-like in two of the three patients (patients 9 and 11 ), and only calf hypertrophy was detected at 7 years of age in patient 10. Patient 11 also had a dilated cardiomyopathy (table 1). All these patients showed a complete absence of $\gamma$-sarcoglycan on immunoblotting.

\section{$\delta$-sarcoglycan}

In one patient a homozygous, novel, missense mutation (R198P) was identified in exon 7 of the $\delta$-sarcoglycan gene. The clinical presentation and disease progression was compatible with a DMD-like phenotype. The patient lost ambulation at 13 years of age (fig 2).

All changes in the four genes were confirmed in the patients' genomic DNA. At least 100 normal chromosomes were tested for each DNA change by either restriction digestion or by SSCP analysis. None of the changes were detected in the control chromosomes.

\section{DISCUSSION}

We have studied molecularly 17 patients showing partial or complete deficiency of $\alpha$-sarcoglycan on muscle biopsy. We have ascertained these patients based on $\alpha$-sarcoglycan immunoblotting results.

Sarcoglycan gene mutations are a well known cause of four forms of limb girdle muscular dystrophies. Identification of gene mutations and their correlations with clinical phenotype have been extensively studied. The clinical presentation of the various sarcoglycanopathies rarely points to a specific gene defect; most of the patients present with proximal muscle weakness, and variability in clinical severity and age of onset have been reported in all four sarcoglycanopathies. As the disease progresses, the selectivity of proximal muscle weakness is lost and all muscle groups except for the facial, ocular, and velopharyngeal groups are involved. ${ }^{7}$ Molecular studies of the four sarcoglycan genes are necessary when the primary abnormality needs to be established.

$\alpha$-sarcoglycan immunohistochemistry in muscle biopsy cryosections is often used to screen for sarcoglycan deficiency based on the assumption that the primary loss of any component of the sarcoglycan complex will lead to the secondary deficiency of all the others. In a previous study using $\alpha$-sarcoglycan immunofluorescence to identify sarcoglycanopathy patients, we reported a mutation detection rate of about $57 \%$ in complete or partial $\alpha$-sarcoglycan deficiency cases. ${ }^{5}$ Here we chose to use $\alpha$-sarcoglycan immunoblotting to screen a large series of undiagnosed limb girdle muscular dystrophy/ myopathy patients assuming that a slight deficiency of $\alpha$-sarcoglycan may be not detected by immunohistochemistry. This assumption proved to be correct in our series, where at least one patient would not have been ascertained by $\alpha$-sarcoglycan immunohistochemistry alone (patient 2, table 1). Indeed, of 17 patients showing partial or complete $\alpha$-sarcoglycan deficiency on their muscle biopsies we were able to identify gene mutations in about $70 \%$ of them (12/17). Of the five mutation negative patients, four had $\alpha$-sarcoglycan reduced to 40 to $50 \%$ of controls by immunoblot and were scored as normal by immunohistochemistry of all four sarcoglycan proteins. It is very likely that these patients have a mild, secondary reduction of the sarcoglycan complex owing to an as yet unknown primary gene defect. The fifth patient is more difficult to interpret. This patient had a severe reduction not only of $\alpha$-sarcoglycan, but also of the other components of the complex, suggesting a primary sarcoglycanopathy. The inability to detect causative gene mutations may be because of the incomplete sensitivity of our mutation detection technique or rare mutations in the promoter or intron sequences. $\alpha$-sarcoglycan immunoblotting identified two patients (patients 2 and 3 ) with a doublet of bands. At least in one case (patient 3) mutations in both $\alpha$-sarcoglycan alleles were identified, but no underlying genetic causes for the additional band were detected. Moreover, in both patients, $\alpha$-sarcoglycan cDNA was completely sequenced and no additional mutations were identified. A possible explanation is that this band may represent a degradation product owing to the instability of the dystrophin-glycoprotein complex following sarcoglycan deficiency itself, as also suggested by the lack of abnormal RT-PCR product consistent with an insertion or deletion.

In 12 patients, 14 different sarcoglycan gene mutations were identified. Novel mutations $(8 / 14)$ were identified in all four sarcoglycan genes and confirmed that mutation type (missense versus nonsense) and site (extracellular versus transmembrane domain) are not predictive of the severity of the clinical phenotype. For example, patient 10 who harboured two null mutations in the $\gamma$-sarcoglycan gene, one in the extracellular and one in the transmembrane domain, has a milder phenotype than patient 9 who harboured a homozygous missense mutation in the extracellular domain of $\gamma$-sarcoglycan. Patient 10 was diagnosed at 4 years of age because of asymptomatic raised serum CK found on routine testing followed by muscle biopsy. At 7 years of age the patient is still asymptomatic and shows only slight calf hypertrophy. Conversely, patient 9 presented at 4 years with proximal muscle weakness, and at 8 years of age the patient had difficulty in climbing stairs and raising herself from the floor and had a marked proximal weakness mostly in the upper limbs. The last clinical evaluation was done at 14 years and showed a marked waddling gait with inability to raise herself from the floor and to lift her arms.

All the mutations identified in the $\alpha$-sarcoglycan gene (eight changes) were in the extracellular domain of the protein and mutations in exon 3 accounted for about $22 \%$ of the mutations identified (2/9), as previously reported. ${ }^{7}$ The clinical phenotype in our genetically proven $\alpha$-sarcoglycan patients varied between high CK with mild calf hypertrophy to a DMD-like presentation, confirming clinical heterogeneity in this subset of patients. The amount of residual $\alpha$-sarcoglycan protein may affect clinical severity; however, patient 7 , with $5 \%$ of residual $\alpha$-sarcoglycan protein, showed only calf hypertrophy at 14 years, while patient 2 with $40 \%$ of the protein presented at 4 years with difficulties in climbing stairs and raising himself from the floor.

The only $\beta$-sarcoglycan null gene mutation we identified was located in the cytoplasmic domain of the protein and was associated with a relatively mild phenotype. Interestingly, this patient had a dilated cardiomyopathy suggesting that $\beta$-sarcoglycan gene mutations result in a reduced capacity of the sarcoglycan complex to transmit force to the extracellular matrix. ${ }^{39} 43$

Four mutations were identified in the $\gamma$-sarcoglycan gene in three patients. $\gamma$-sarcoglycan protein was completely absent from all three patients' muscle biopsy; however, a single patient had a mild phenotype suggesting that a defective sarcoglycan complex lacking some components may still be assembled and attached to the plasma membrane, or a single sarcoglycan may be bound to the membrane by an unknown mechanism. ${ }^{44} \delta$-sarcoglycanopathy is the rarest sarcoglycanopathy with only a few mutation reported. ${ }^{1321232645}$ We identified a novel homozygous missense mutation in a patient presenting with a severe DMD-like phenotype who lost ambulation at 13 years of age.

In conclusion, our study suggests that protein analysis should precede sarcoglycan gene analysis and that screening 
for common mutations is worthwhile only in a specific patient population.

\section{ACKNOWLEDGEMENTS}

This work was supported by a grant from the Italian Telethon (No 1114), Telethon bank (No GTF02009), and MURST (No 2001068328).

\section{Authors' affiliations}

C Boito, M Fanin, C Angelini, E Pegoraro, Department of Neurological and Psychiatric Sciences, University of Padova, Italy G Siciliano, Department of Neurosciences, University of Pisa, Italy

Correspondence to: Dr E Pegoraro, Department of Neurological and Psychiatric Sciences, University of Padova, Via Giustiniani 5, 35128 Padova, Italy; elena.pegoraro@unipd.it.

\section{REFERENCES}

1 Worton R. Muscular dystrophies: diseases of the dystrophin-glycoprotein complex. Science 1995;270:755-6.

2 Straub V, Campbell KP. Muscular dystrophies and the dystrophin-glycoprotein complex. Curr Opin Neurol 1997:10:168-75.

3 Ozawa E, Yoshida M, Suzuki A, Hagiwara Y, Noguchi S. Dystrophin-associated proteins in muscular dystrophy. Hum Mol Genet 1995;4:1711-16

4 Dincer $\mathbf{P}$, Leturcq F, Richard I, Piccolo F, Yalnizoglu D, de Toma C, Akcoren Z, Broux O, Deburgrave N, Brenguier L, Roudaut C, Urtizberea JA, Jung D, Tan E, Jeanpierre M, Campbell KP, Kaplan JC, Beckmann JS, Topaloglu $\mathrm{H}$. A biochemical, genetic, and clinical survey of autosomal recessive limb girdle muscular dystrophies in Turkey. Ann Neurol 1997;42:222-9.

5 Duggan DJ, Gorospe JR, Fanin M, Hoffman EP, Angelini C, Pegoraro E, McNally E, Bonneman CG, Kunkel LM, Noguchi S, Ozawa E, Pendlenbury W, Oechler H, Waclawik A, Duenas DA, Hutchison T, Hausmanowa-Petrusewicz I, Fidzianska A, Bean SC, Haller JS, Bodensteiner J, Greco C, Pestronk A, Berardinelli A, Gelinas DF, Abram $\mathrm{H}$, Kuncl RW. Mutations in the sarcoglycan genes in patients with myopathy. N Engl J Med 1997;336:618-24.

6 Fanin M, Duggan DJ, Mostacciuolo ML, Martinello F, Freda MP, Soraru $G$, Trevisan CP, Hoffman EP, Angelini C. Genetic epidemiology of muscular dystrophies resulting from sarcoglycan gene mutations. J Med Genet 1997;34:973-7.

7 Bushby KM. Making sense of the limb-girdle muscular dystrophies. Brain 1999; 122:1403-20.

8 Vainzof $M$, Passos-Bueno MR, Pavanello RCM, Marie SK, Oliveira ASB, Zatz M. Sarcoglycanopathies are responsible for $68 \%$ of severe autosomal recessive limb-girdle muscular dystrophy in the Brazilian population. J Neurol Sci 1999;164:44-9.

9 Roberds SL, Leturcq F, Allamand V, Piccolo F, Jeanpierre M, Anderson RD, Lim LE, Lee JC, Tome' FM, Romero NB. Missense mutations in the adhalin gene linked to autosomal recessive muscular dystrophy. Cell 1994;78:625-33.

10 Noguchi S, McNally E, Ben Othmane K, Hagiwara Y, Mizuno Y, Yoshida M, Yamamoto H, Bonnemann CG, Gussoni E, Denton PH, Kyriakides T, Middleton L, Hentati F, Ben Hamida M, Nonaka I, Vance JM, Kunkel LM, Ozawa E. Mutations in the dystrophin-associated protein $\gamma$-sarcoglycan in chromosome 13 muscular dystrophy. Science 1995;270:819-22

11 Bonnemann CG, Modi R, Noguchi S, Mizuno Y, Yoshida M, Gussoni E, McNally EM, Duggan DJ, Angelini C, Hoffman EP. $\beta$-sarcoglycan (A3b) mutations cause autosomal recessive muscular dystrophy with loss of the sarcoglycan complex. Nat Genet 1995;11:266-73.

$12 \operatorname{Lim}$ LE, Duclos F, Broux O, Bourg N, Sunada Y, Allamand V, Meyer J, Richard I, Moomaw C, Slaughter C, Tome' FMS, Fardeau M, Jackson $\mathrm{CE}$, Beckmann JS, Campbell KPI. $\beta$-sarcoglycan: characterization and role in limb-girdle muscular dystrophy linked to $4 q 12$. Nat Genet $1995 ; 11: 257-64$

13 Nigro V, de Sa Moreira E, Piluso G, Vainzof M, Belsito A, Politano L, Puca AA, Passos-Bueno MR, Zatz M. Autosomal recessive limb-girdle muscular dystrophy LGMD2F is caused by a mutation in the delta-sarcoglycan gene. Nat Genet 1996;14:195-8.

14 Piccolo F, Roberds SL, Jeanpierre M, Leturcq F, Azibi K, Beldjord C, Carrie A, Recan D, Chaouch M, Reghis A, El Kerch F, Sefiani A, Voit T, Merlini L, Collin H, Eymard B, Beckmann JS, Romero NB, Tome' FMS, Fardeau M, Campbell KP, Kaplan JC. Primary adhalinopathy: a common cause of autosomal recessive muscular dystrophy of variable severity. Nat Genet 1995;10:243-5.

15 Bonnemann CG, Passos-Bueno MR, McNally EM, Vainzof $M$, de Sa Moreira E, Marie SK, Pavanello RC, Noguchi S, Ozawa E, Zatz M, Kunkel LM. Genomic screening for $\beta$-sarcoglycan gene mutations: missense mutations may cause severe limb-girdle muscular dystrophy type 2E (LGMD2E). Hum Mol Genet 1996:5:1953-61.

16 Bonnemann CG, Wong J, Ben Hamida C, Ben Hamida M, Hentati F, Kunkel LM. LGMD2E in Tunisia is caused by a homozygous missense mutation in $\beta$-sarcoglycan exon 3. Neuromusc Disord 1998;8: 193-7.

17 Kawai H, Akaike M, Endo T, Adachi K, Inui T, Mitsui T, Kashiwagi S, Fujwara T, Okuno S, Shin S, Miyoshi K, Campbell KP, Yamada H,
Shimizu T, Matsumura K, Saito S. Adhalin gene mutations in patients with autosomal recessive childhood onset muscular dystrophy with adhalin deficiency. J Clin Invest 1995;96:1202-7

18 McNally EM, Duggan D, Gorospe JR, Bonnemann CG, Fanin M, Pegoraro E, Lidov HG, Noguchi S, Ozawa E, Finkel RS, Cruse RP, Angelini C, Kunkel LM, Hoffman EP. Mutations that disrupt the carboxyl-terminus of gamma-sarcoglycan cause muscular dystrophy. Hum Mol Genet 1996;5:1841-7.

19 Piccolo F, Jeanpierre M, Leturcq F, Dode C, Azibi K, Toutain A, Merlini L, Jarre L, Navarro C, Krishnamoorthy R, Tome' FM, Urtizberea JA, Beckmann JS, Campbell KP, Kaplan JC. A founder mutation in the $\gamma$-sarcoglycan gene of Gypsies possibly predating their migration out of India. Hum Mol Genet 1996;5:2019-22.

20 Carriè A, Piccolo F, Leturcq F, de Toma C, Azibi K, Beldjord C, Vallat JM, Merlini L, Voit T, Sewry C, Urtizberea JA, Romero N, Tome' FM, Fardeau M, Sunada Y, Campbell KP, Kaplan JC, Jeanpierre M. Mutational diversity and hot spots in the $\alpha$-sarcoglycan gene in autosomal recessive muscular dystrophy (LGMD2D). J Med Genet 1997;34:470-5.

21 Duggan DJ, Manchester D, Stears KP, Mathews DJ, Hart C, Hoffman EP. Mutations in the $\delta$-sarcoglycan gene are a rare cause of autosomal recessive limb-girdle muscular dystrophy. Neurogenetics 1997;1:49-58.

22 Duclos F, Broux O, Bourg N, Straub V, Feldman GL, Sunada Y, Lim LE, Piccolo F, Cutshall S, Gary F, Ouetier F, Kaplan JC, Jackson CE, Beckmann JS, Campbell KP. $\beta$-sarcoglycan: genomic analysis and identification of a novel missense mutation in the LGMD2E Amish isolate. Neuromusc Disord 1998:8:30-8.

23 Moreira ES, Vainzof M, Marie SK, Nigro V, Zatz M, Passos-Bueno MR. A first missense mutation in the $\delta$-sarcoglycan gene associated with a severe phenotype and frequency of limb-girdle muscular dystrophy type 2F (LGMD2F) in Brazilian sarcoglycanopathies. J Med Genet 1998;35:951-3.

24 Urtasun M, Saenz A, Roudaut C, Poza JJ, Urtizberea JA, Cobo AM, Richard I, Garcia Bragado F, Leturcq F, Kaplan JC, Marti Masso JF, Beckmann JS, Lopez de Munain A. Limb-girdle muscular dystrophy in Guipuzcoa (Basque Country, Spain). Brain 1998;121:1735-47.

25 Van der Kooi AJ, De Visser M, Van Meengrn M, Ginjaar HB, van Essen AJ, Jennekens FG, Jongen PJ, Leschot NJ, Bolhuis PA. A novel $\gamma$-sarcoglycan mutation causing childhood onset, slowly progressive limb-girdle muscular dystrophy. Neuromusc Disord 1998;8:305-8.

26 Dincer P, Bonnemann CG, Aker O, Akcoren Z, Nigro V, Kunkel LM, Topaloglu $\mathrm{H}$. A homozygous nonsense mutation in $\delta$-sarcoglycan exon 3 in a case of LGMD2F. Neuromusc Disord 2000;10:247-50.

27 Merlini L, Kaplan JC, Navaro C, Barois A, Bonneau D, Brasa J, Echenne B, Gallano P, Jarre L, Jeanpierre M, Kalaydijeva L, Leturca F, Levi-Gomes A, Toutain A, Tournev I, Urtizberea A, Vallat JM, Voit T, Warter JM. Homogeneous phenotype of the gypsy limb-girdle $M D$ with the $\gamma$-sarcoglycan C283Y mutation. Neurology 2000;54: 1075-9

28 Vainzof M, Moreira ES, Canovas M, Anderson LV, Pavanello RC, Passos-Bueno MR, Zatz M. Partial $\alpha$-sarcoglycan deficiency with retention of the dystrophin-glycoprotein complex in a LGMD2D family. Muscle Nerve 2000;23:984-8.

29 Ben Hamida M, Ben Hamida C, Zouari M, Belal S, Hentati F. Limb-girdle muscular dystrophy $2 \mathrm{C}$ : clinical aspects. Neuromusc Disord 1996:6:493-4

30 Ginjaar HB, Van der Kooi AJ, Ceelie H, Kneppers AL, vanMeegen M Barth PG, Busch HF, Wokke JH, Anderson LV, Bonnemann CG Jeanpierre M, Bolhuis PA, Moorman AF, de Visser M, Bakker E, Ommen GJ. Sarcoglycanopathies in Dutch patients with autosomal recessive limb girdle muscular dystrophy. J Neurol 2000;247:524-9.

31 Holt KH, Campbell KP. Assembly of the sarcoglycan complex. J Biol Chem 1998;273:34667-70.

32 Matsumura K, Campbell KP. Deficiency of dystrophin-associated proteins: a common mechanism leading to muscle cell necrosis in severe childhood muscular dystrophy. Neuromusc Disord 1993:3:109-18

33 Hack AA, Lam M, Cordier L, Shoturma DI, Ly CT, Hadhazy MA, Hadhazy MR, Sweeney HL, MCNally EM. Differential requirement for individual sarcoglycans and dystrophin in the assembly and function of the dystrophin-glycoprotein complex. J Cell Sci 2000;1 13:2535-44.

34 Yamada H, Saito F, Fukuta-Ohi H, Zhong D, Hase A, Arai K, Okuyama A, Maekawa R, Shimizu T, Matsumura K. Processing of $\beta$-dystroglycan by matrix metalloproteinase disrupts the link between the extracellular matrix and cell membrane via the dystroglycan complex. Hum Mol Genet 2001;10:1563-9.

35 Angelini C, Fanin M, Menegazzo E, Freda MP, Duggan DJ, Hoffman EP. Homozygous $\alpha$-sarcoglycan mutation in two siblings: one asymptomatic and one steroid responsive mild limb-girdle muscular dystrophy patient. Muscle Nerve 1998;21:769-75.

36 Takano A, Bonnemann CG, Honda H, Sakai M, Feener CA, Kunkel LM Sobue $G$. Intrafamilial phenotypic variation in the limb-girdle muscular dystrophy type $2 \mathrm{C}$ with compound heterozygous mutations. Muscle Nerve 2000;23:807-10

37 Van der Kooi AJ, Barth PG, Busch HFM, de Haan R, Ginjaar HB, van Essen $A J$, van Hooff $L$, Howeler CJ, Jennekens FG, Jongen $P$, Oosterhuis HJ, Padberg GW, Spaans F, Wintzen AR, Wokke JH, Bakker E, van Ommen GJ, Bolhuis PA, de Visser M. The clinical spectrum of limb girdle muscular dystrophy: a survey in the Netherlands. Brain 1996;1 19:1471-80

38 Angelini C, Fanin M, Freda MP, Duggan DJ, Siciliano G, Hoffman EP The clinical spectrum of sarcoglycanopathies. Neurology 1999;52:176-9. 
39 Barresi R, Di Blasi C, Negri T, Brugnoni R, Vitali A, Felisari G, Salandi A, Danieli S, Cornelio F, Morandi L, Mora M. Disruption of heart sarcoglycan complex and severe cardiomyopathy caused by $\beta$-sarcoglycan mutations. J Med Genet 2000;37:102-7.

40 Cagliani R, Comi GP, Tancredi L, Sironi M, Fortunato F, Giorda R, Bardoni A, Moggio M, Pelle A, Bresolin N, Scarlato G. Primary beta-sarcoglycanopathy manifesting as recurrent exercise-induced myoglobinuria. Neuromusc Disord 2000; 11:389-94.

41 Anderson LVB. Optimized protein diagnosis in the autosomal recessive limb-girdle muscular dystrophies. Neuromusc Disord 1996;6:443-6.

42 Pegoraro E, Cepollaro F, Prandini P, Marin A, Fanin M, Trevisan CP, El-Messlemani AH, Tarone G, Engrall E, Hoffman EP, Angelini C. Integrin $\alpha 7 \beta 1$ in muscular dystrophy/myopathy of unknown etiology. Am J Pathol 2002;160:2135-43.

43 Lim LE, Campbell KP. The sarcoglycan complex in limb-girdle muscular dystrophy. Curr Opin Neurol 1998;11:443-52.

44 Ozawa E, Noguchi S, Mizuno Y, Hagiwara Y, Yoshida M. From dystrophinopathy to sarcoglycanopathy: evolution of a concept of muscular dystrophy. Muscle Nerve 1998;21:421-38.

45 Tsubata S, Bowles KR, Vatta M, Zintz C, Titus J, Muhonen L, Bowles NE, Towbin JA. Mutations in the human $\delta$-sarcoglycan gene in familial and sporadic dilated cardiomyopathy. J Clin Invest 2000;106:655-62. 